\title{
Penyuluhan Kenali dan Waspadai Bahaya Demam Berdarah Dengue bagi Warga Desa Tanah Datar Kecamatan Muara Badak
}

\author{
Suwignyo ${ }^{1}$, Agustinus Ola Maran ${ }^{2}$ \\ ${ }^{12}$ Universitas Widyagama Mahakam Samarinda \\ * Email korespondensi: wigbohc@gmail.com, (081350550108)
}

Received: 30 Desember 2020; Revision: 10 Februari 2021; Accepted: 30 Maret 2021

\begin{abstract}
Abstrak
Penyakit Demam Berdarah Dengue banyak menjangkiti di daerah Asia. DBD hampir selalu ada pada setiap tahunnya dan menjadi masalah kesehatan dan terjadi kematian di Indonesia. Penyakit ini masih menjadi momok terhadap penduduk Indonesia dan khususnya Kalimantan Timur. Dan ditunjang dengan kondisi geografis Kalimantan Timur yang yang curah hujan yang cukup tinggi sehingga menunjang perkembang biakan vektor nyamuk Aedes aeugepty dan Albopictus. Ini berarti akan menjadi masalah yang harus diatasi secara terus menerus guna mencapai derajat kesehatan masyarakat yang tinggi. Desa Tanah Datar Kecamatan Muara Badak mempunyai potensi risiko yang tinggi terhadap pencemaran lingkungan juga terdapat perkebunan sawit, karet dan lahan pertanian lainnya. Selain itu terdapat pertambangan batubara dan migas yang tentunya ada risiko-risiko terhadap perubahan kondisi lingkungan di wilayah tersebut. Tujuan pengabdian masyarakat ini adalah memberikan informasi kepada masyarakat tentang penyakit Demam Berdarah Dengue dan upaya pemberatasan dan pengendaliannya dengan 4M juga mendorong kepada pemerintah Desa agar berperan aktif dalam upaya pencegahan dan pengendaliannya, yang dilaksanakan pada bulan Desember 2019. Metode yang digunakan adalah ceramah dan tanya jawab serta sharing. Sasaran pengabdian adalah warga dan perangkat desa Tanah Datar Kecamatan Muara Badak.
\end{abstract}

Kata Kunci : Penyuluhan, Demam Berdarah Dengue, 4M

Suwignyo, S., \& Maran, A. (2021). Penyuluhan Kenali dan Waspadai Bahaya Demam Berdarah Dengue bagi Warga Desa Tanah Datar Kecamatan Muara Badak. Masyarakat Berdaya dan Inovasi, 2(1), 54 - 57. doi:https://doi.org/10.33292/mayadani.v2i1.30

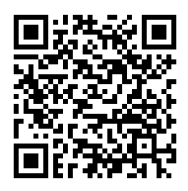

This is an open access article under the CC-BY-SA license.

\section{PENDAHULUAN}

Demam Berdarah Dengue banyak ditemukan di daerah tropis dan sub-tropis. Data dari seluruh dunia menunjukkan Asia menempati urutan pertama dalam jumlah penderita DBD setiap tahunnya. Sementara itu, terhitung sejak tahun 1968 hingga tahun 2009, World Health Organization (WHO) mencatat negara Indonesia sebagai negara dengan kasus DBD tertinggi di Asia Tenggara. (Kemenkes RI, 2010). Penyakit ini disebabkan oleh salah satu dari empat serotipe virus dari genus Flavivirus, famili Flaviviridae. Setiap serotipe cukup berbeda sehingga tidak ada proteksi-silang dan wabah yang disebabkan beberapa serotipe 
(hiperendemisitas) dapat terjadi. DBD disebarkan kepada manusia oleh nyamuk Aedes aegypti.

Demam Berdarah Dengue (DBD) merupakan masalah utama kesehatan masyarakat di Indonesia dan angka kematian DBD. Angka kesakitan DBD pada tahun 2017 yang tertinggi adalah Bali dengan 105,95 per 10.000 dan disusul dengan Kalimantan Timur dengan 62,57 dan urutan ketiga adalah Kalimantan Barat dengan 52,61 per 10.000 penduduk. Walaupun angka ini sudah ada penurunan dari tahun 2016. (Pusdatin Kemenkes, 2017).

Dengan melihat data tersebut diatas menunjukkan bahwa penyakit Demam Berdarah Dengue masih menjadi momok penyakit menular terhadap penduduk Indonesia dan khususnya Kalimantan Timur. Dan ditunjang dengan kondisi geografis Kalimantan Timur yang yang curah hujan yang cukup tinggi sehingga menunjang perkembang biakan vector nyamuk Aedes aigepty dan Albopictus. Ini berarti akan menjadi masalah yang harus diatasi secara terus menerus guna mencapai kesehatan masyarakat pada tujuan kesehatan bagi bangsa Indonesia. Secara terus menerus ada penelitian guna mengatasi atau mengurangi penyakit demam berdarah ini namun belum bisa tuntas.

Daerah Kecamatan Muara Badak dan Marangkayu adalah wilayah yang mempunyai kondisi geografis, demografis dan potensi risiko yang tinggi terhadap pencemaran terhadap lingkungan. Secara geografis terletak di dekat pantai, banyak lahan rawa dan hutan semak. Selain itu wilayahnya kurang lebih $1-2$ jam untuk mencapai kota yang terdekat. Juga terdapat perkebunan sawit, karet dan lahan pertanian lainnya. Selain itu terdapat pertambangan batubara dan migas yang tentunya ada risiko-risiko terhadap perubahan kondisi lingkungan di wilayah tersebut.

Secara teori bahwa penyakit DBD ada faktor-faktor yang menjadi mempengaruhi yaitu pada host, agent dan environment. Disisi agent atau penyebab jelas adalah virus Dengue yang memang keberadaannya tumbuh baik pada daerah yang beriklim tropis maupun subtropics, namun dari sisi host atau penjamu atau manusianya dengan kondisi gizi masyarakat, perilaku dan sisi lingkungan seperti iklim, cuaca kelembapan lingkungan sekitar dan terutama pada rumah tempat tinggalnya yang harus dilakukan upaya untuk menyelesaikan masalah penyakit Demam Berdarah ini.

Pengendalian DBD yang utama adalah dengan memutus rantai penularan yaitu dengan pengendalian vektornya, karena sampai saat ini vaksin dan obatnya belum ada. Vektor DBD yaitu nyamuk Aedes aegypti dan Aedes albopictus pengendaliannya tidak mungkin berhasil dengan baik kalau hanya dilakukan oleh sektor kesehatan, karena berbasis lingkungan dan nyamuk Aedes berkembang biak di wilayah permukiman penduduk. Untuk mencegah resistensi dan effektifitas, maka penggunaan insektisida harus selektif, tepat sasaran, tepat dosis, tepat waktu, tepat cakupan. Peran serta masyarakat dan lintas sektor terkait harus ditingkatkan secara berkesinambungan melalui penyuluhan dan promosi kesehatan untuk mengendalikan sumber nyamuk melalui 4M plus atau PSN terpadu. Untuk meningkatkan daya ungkit pengendalian DBD akan terlaksana dengan baik kalau digerakkan oleh Kementerian dalam negeri termasuk pemerintah daerah di semua tingkat administrasi dan dukungan dukungan teknik dari sektor kesehatan. Mengingat pentingnya pencegahan, penanggulangan dan pemberantasan Demam Berdarah Dengue ini oleh karena itu akan diselenggarakan pengadian kepada masyarakat berjudul Kenali Dan Waspadai Bahaya Demam Berdarah bagi Warga Desa Tanah Datar Kecamatan Muara Badak.

\section{METODE}

Metode yang digunakan dalam kegiatan ini adalah ceramah dan tanya jawab. Ceramah dilakukan untuk mensosialisasikan informasi tentang epidemi, pemberantasan dan penanggulangan DBD. Selain itu metode ini dipadu dengan tanya jawab dengan tujuan terjadi 
kedekatan antara civitas akademika (tim Pengambdian) dan masyarakat. Tanya jawab diharapkan akan lebih menghidupkan suasana kegiatan pengabdian berupa tanya jawab, diskusi, sharing berbagai informasi tentang DBD. Sehingga setelah sosialisasi dilakukan, masyarakat Desa Tanah Datar dapat lebih berperan aktif dalam pemberantasan dan penanggulangan DBD

\section{HASIL DAN PEMBAHASAN}

Kegiatan ini dilakukan sebanyak 2 kali yaitu kegiatan penyuluhan ke warga Desa Tanah Datar dan yang kedua ada pertemuan dengan Pjs Kepala Desa di Kantor Desa Tanah Datar.

Hasil dari kegiatan penyuluhan tentang kenali dan waspadai bahaya demam berdarah di Desa Tanah Datar adalah upaya untuk memberi pengetahuan dan pemahaman definisi, penyebab dan faktor yang menyebabkan penularan penyakit demam baerdarah kepada warga desa Tanah Datar. Juga termasuk upaya pengendalian terhadap perkembangan nyamuk Aedes aegypti dan Aedes albopictus yang merupakan vektor dari penyakit DBD. Yang hadir pada kegiatan tersebut berjumlah 50 orang warga. Respon warga terhadap penyuluhan antusias dan menyimak dengan seksama.

Pada saat penyuluhan ada beberapa pertanyaan oleh warga, ini membuktikan ketertarikan akan informasi yang disampaikan. Dan pada akhir penyuluhan dilakukan evaluasi dengan cara penyuluh memberikan pertanyaan yang bisa dijawab oleh warga secara bersama. Kecuali itu tim pengabdian masyarakat juga bertemu dengan Pjs Kepala Desa Tanah Datar guna menyambung informasi dan memberi dorongan kepada pemerintah desa agar menjadi perhatian dalam upaya pengendalian penyakit Demam Berdarah diwilayah kerjanya.

\section{SIMPULAN}

Penyuluhan tentang kenali dan waspadai bahaya demam berdarah Bagi warga di desa Tanah Datar, memberikan informasi bagaimana upaya pencegahan terhadap penularan penyakit dan pengendalian vector nyamuk aedes aigypti dan albopictus.

1. Peserta mengikuti penyuluhan dengan seksama sehingga mengerti tentang DBD dan upaya pengendaliannya. Dengan bukti peserta dengan serius dan menyimak selama penyuluhan dan dapat menjawab pertanyaan yang direview oleh penyuluh.

2. Pemerintah Desa menerima penyuluh dan tim di ruang kerja PJS Kepala Desa untuk berdiskusi kaitannya dengan upaya pencegahan dan pengendaliah DBD.

\section{UCAPAN TERIMA KASIH}

Tim pengabdian berterima kasih kepada seluruh anggota pengabdian dan Universitas Widya Gama Mahakam Samarinda yang telah membantu dalam proses pengabdian dan memberikan dukungannya.

\section{DAFTAR PUSTAKA}

Achmadi Umar Fahmi. 2013. Dasar-Dasar Penyakit Berbasis Depkes RI. 1992. Petunjuk Teknis Penemuan, Pertolongan, dan Pelaporan Penderita Penyakit DBD. Dirjen PPM dan PLP.

Ditjen P2M\&PLP. 2001. Petunjuk Teknis Pemberantasan Nyamuk Penular Penyakit Demam Berdarah Dengue. Departemen Kesehatan RI. Jakarta 
Hartanto, 2007. D. Waspada Demam Berdarah. http://www.dinkespurworejo.go.id/ndex.php? option $=$ com content\&task $=$ view $\& i d=12 \&$ Itemid $=3$ (diakses Agustus 2019).

Kemenkes. 2018.Situasi Penyakit DBD di Indonesia 2017. Infodatin.

Sukowati Suratman. 2010. Masalah penyakit Demam Berdarah Dengue DBD dan Pengendaliannya di Indonesia. Puslitbang Ekologi dan Status Kesehatan, Jakarta 